\title{
Correction to: Futurizing politics and the sustainability of real-world experiments: what role for innovation and exnovation in the German energy transition?
}

\author{
Martin David ${ }^{1} \cdot$ Matthias Gross $^{1,2}$
}

Published online: 23 December 2020

(c) The Author(s) 2020

\section{Correction to: Sustainability Science (2019) 14:991-1000 https://doi.org/10.1007/s11625-019-00681-0}

The article Futurizing politics and the sustainability of realworld experiments: what role for innovation and exnovation in the German energy transition?, written by Martin David and Matthias Gross, was originally published Online First without Open Access. After publication in volume 14, issue 4, page 991-1000 the author decided to opt for Open Choice and to make the article an Open Access publication. Therefore, the copyright of the article has been changed to $($ ) The Author(s) 2020 and the article is forthwith distributed under the terms of the Creative Commons Attribution 4.0 International License, which permits use, sharing, adaptation, distribution and reproduction in any medium or format, as long as you give appropriate credit to the original author(s) and the source, provide a link to the Creative Commons licence, and indicate if changes were made. The images or other third party material in this article are included in the article's Creative Commons licence, unless indicated otherwise in a credit line to the material. If material is not included in the article's Creative Commons licence and your intended use is not permitted by statutory regulation or exceeds the permitted use, you will need to obtain permission directly from the copyright holder. To view a copy of this licence, visit https://creativecommons.org/licenses/by/4.0/.

The original article has been updated.

Open Access This article is licensed under a Creative Commons Attribution 4.0 International License, which permits use, sharing, adaptation, distribution and reproduction in any medium or format, as long as you give appropriate credit to the original author(s) and the source, provide a link to the Creative Commons licence, and indicate if changes were made. The images or other third party material in this article are included in the article's Creative Commons licence, unless indicated otherwise in a credit line to the material. If material is not included in the article's Creative Commons licence and your intended use is not permitted by statutory regulation or exceeds the permitted use, you will need to obtain permission directly from the copyright holder. To view a copy of this licence, visit http://creativecommons.org/licenses/by/4.0/.

Publisher's Note Springer Nature remains neutral with regard to jurisdictional claims in published maps and institutional affiliations.

The original article can be found online at https://doi.org/10.1007/ s11625-019-00681-0.
Martin David
martin.david@ufz.de
https://www.ufz.de
Matthias Gross
matthias.gross@ufz.de
1 Helmholtz Centre for Environmental Research GmbH - UFZ, Permoserstraße, 15, 04318 Leipzig, Germany
2 Institute of Sociology, University of Jena, Jena, Germany 